
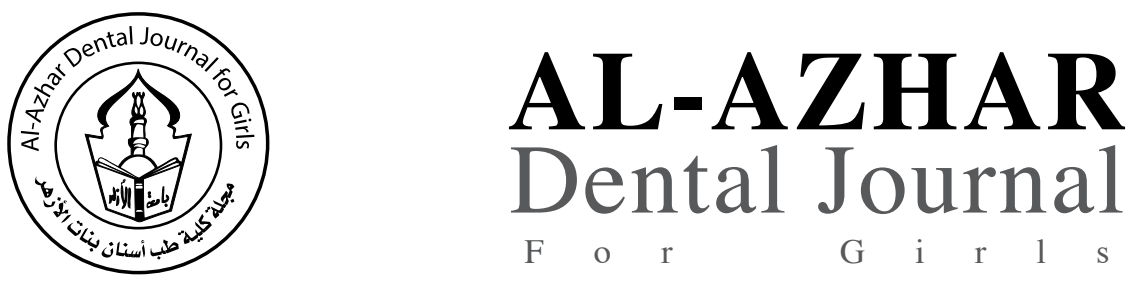

The Official Publication of The Faculty of Dental Medicine For Girls, Al-Azhar University Cairo, Egypt.

ADJ-for Grils, Vol. 4, No. 4, October (2017) - PP. 381:384

\title{
Effects of Vitamin D on Growth Inhibition of Head and Neck Squamous Cell Carcinoma. (In vitro study)
}

\section{Heba Hussein ${ }^{(1)}$}

Codex : 44/1710

Heba_Hussein@dentistry.cu.edu.eg

\section{KEYWORDS}

Head and neck squamous cell carcinoma, vitamin D, apoptosis

\begin{abstract}
Objective: To assess the anti-cancer capacity of vitamin D in head and neck squamous cell carcinoma cell line. Materials and Methods: vitamin D cytotoxic effect and cell apoptosis effect were evaluated using Prestoblue cell viability assay and Flow Cytometry. Results: Vitamin D was found to inhibit the cell growth in a dose-dependent manner in head and neck squamous cell carcinoma JHU-29 cell line at three days' treatment. However, it was not found to cause significant apoptosis at one day treatment. Conclusion: vitamin D inhibits the growth of head and neck squamous cell carcinoma in a dose-dependent manner.
\end{abstract}

\section{INTRODUCTION}

Head and neck malignancy is one of the most commonly diagnosed malignancies worldwide. Patients with advanced disease stages frequently develop either recurrences or distant metastasis, which result in a five-year survival rates of nearly $50 \%$ in spite of the considerable advances in multimodality treatment. Therefore, a better understanding of the molecular basis of carcinogenesis is required to develop novel diagnostic biomarkers, and to develop new anti-cancer therapies ${ }^{(I)}$

The active vitamin D metabolite calcitriol has many functions besides its classical biological effects on calcium and phosphorus homeostasis. Calcitriol has a broad variety of actions including anticancer effects that are mediated either transcriptionally or via non-genomic pathways. In cancer, calcitriol regulates the cell cycle, induces apoptosis, promotes cell differentiation and acts as anti-inflammatory factor within the tumor microenvironment ${ }^{(2)}$.

Current cancer therapies have many side effects which may include facial disfigurement. That necessitated the search for more anti-cancer 
options and vitamin D deemed as a promising anticancer agent. Based upon the above, we hypothesized that vitamin D would inhibit head and neck cancer cell line growth.

\section{MATERIALS AND METHODS}

All cells were grown as adhesive monolayers in a humidified atmosphere of $5 \% \mathrm{CO}_{2}$ in air at $37^{\circ} \mathrm{C}$ (2). The medium components included: RPMI 1640 medium fortified with $10 \%$ fetal bovine serum, $1 \%$ Penicillin-Streptomycin, 1\% Sodium Pyruvate, 1\% MEM Nonessential amino acids, and $1 \%$ L-glutamate. Cells in the current experiment were sub-cultured every other day using $0.05 \%$ trypsin for two minutes.

\section{PrestoBlue cell viability assay}

Cells were seeded at an initial density of 5000 cells per well in a flat-bottom 96-well cell culture plate and allowed to grow in $200 \mathrm{ul}$ growth medium per well for 24 hours in a humidified $5 \% \mathrm{CO}_{2}, 95 \%$ air atmosphere in an incubator kept at $37^{\circ} \mathrm{C}$. The old medium was aspirated, and $200 \mathrm{ul}$ of vitaminmedium mixture was added in concentrations of $10^{-6}, 10^{-8}$ and $10^{-9} \mathrm{M}$ in six replicates for each concentration to compensate for technical errors. Medium with $0.1 \%$ DMSO was added to other six replicates as a control. The cells were incubated for other three days.

Prestoblue solution (PrestoBlue Cell Viability Reagent was manufactured by Thermo Fisher Scientific Inc.) was added according to the manufacturer's instructions. The plate was scanned with an OptiMax microplate reader (VersaMax microplate reader by Molecular Devices, Sunnyvale, CA.) at an absorbance mood using an excitation wavelength of $560 \mathrm{~nm}$ and an emission wavelength of $600 \mathrm{~nm}$.

The data was converted into the relative cell viability (\%) from the absorbance of cells in each treatment concentration relative to that in the solvent only control group (set as $100 \%$ ).

\section{Flow cytometry to analyze cell apoptosis:}

Cell apoptosis was analyzed using a flow cytometer with FITC Annexin V Apoptosis Detection Kit I (BD Biosciences, San Diego, CA). One day after treatment with $1,25(\mathrm{OH})_{2} \mathrm{D} 3$ or DMSO vehicle, or ethanol. Cell apoptosis was analyzed. Pelleted cells from each sample were washed twice with cold PBS then resuspended in $1 \mathrm{X}$ binding buffer diluted with nine parts distilled water at a concentration of $1 \mathrm{x}$ $10^{6}$ cells $/ \mathrm{ml}$. Cells from each sample were separated into four tubes. Each tube was received either a $5 \mathrm{ul}$ of FITC Annexin or $5 \mathrm{ul}$ Propidium Iodide (PI) or both or neither, and then incubated at room temperature for $15 \mathrm{~min}$ in the dark. Another 400 ul binding buffer was added to each tube. Samples were transferred into flow cytometry tubes and analyzed within one hour using a flow cytometer BD (FACSVerse manufactured by BD Biosciences, San Diego, CA.). The cell population was divided into three groups: live cells, apoptotic cells in the earlier period (Annexin $\mathrm{V}$ positive), and necrotic and advanced stage apoptotic cells (Annexin V and PI positive).

\section{RESULTS}

$1,25(\mathrm{OH})_{2} \mathrm{D} 3$ added to JHU-29 cell line inhibited cell proliferation at three concentrations $10^{-9}$, $10^{-8}$, and $10^{-6}$ Molar after three days of treatment. The cell viability decreased in a dose-dependent manner from $100 \%$ to $66 \%$ with increasing $1,25(\mathrm{OH})_{2} \mathrm{D} 3$ concentrations as shown in figure.

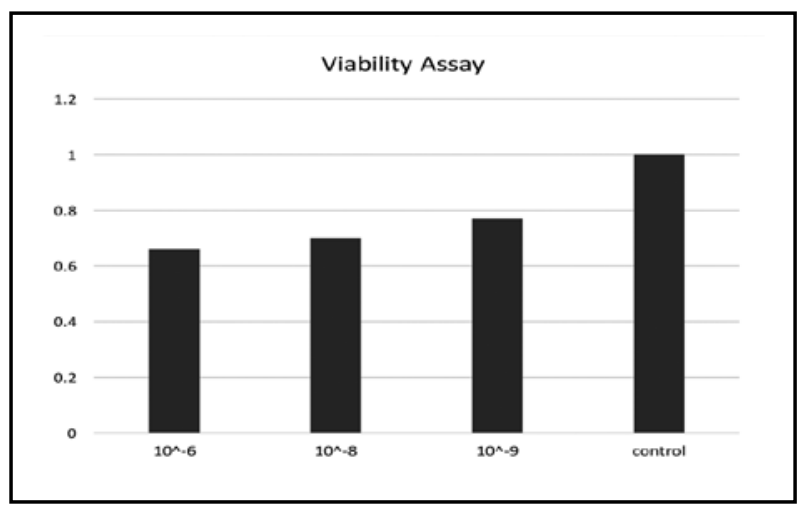

Fig. (1) A bar graph of the cell viability percentage (vertical line) at three different doses (horizontal line) after administration of $1,25(\mathrm{OH}) 2 \mathrm{D} 3$ OSCC cell line for three days. 


\section{Flow Cytometry results:}

Flow cytometry apoptosis assay compared the cell apoptosis after a one day treatment of DMSO or $1,25(\mathrm{OH})_{2} \mathrm{D} 3$. Live cells are those cells which are annexin $\mathrm{V}$ negative and are located at the lower left (LL) quadrant. Apoptotic cells are those which bind to annexin $\mathrm{V}$ stain and are located at the lower right (LR) quadrant. The distribution of live and apoptotic cells in the control and vitamin D- treated groups are shown in figures respectively.

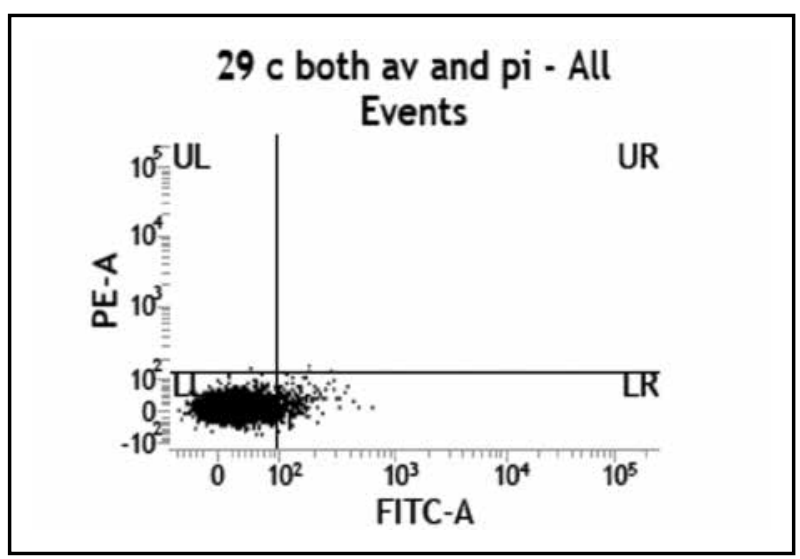

Fig. (2) Apoptotic changes in the control cells as shown on the Flow Cytometer machine. AV: Annexin V, UL: upper right, UR: upper right, LL: lower left, LR: lower right

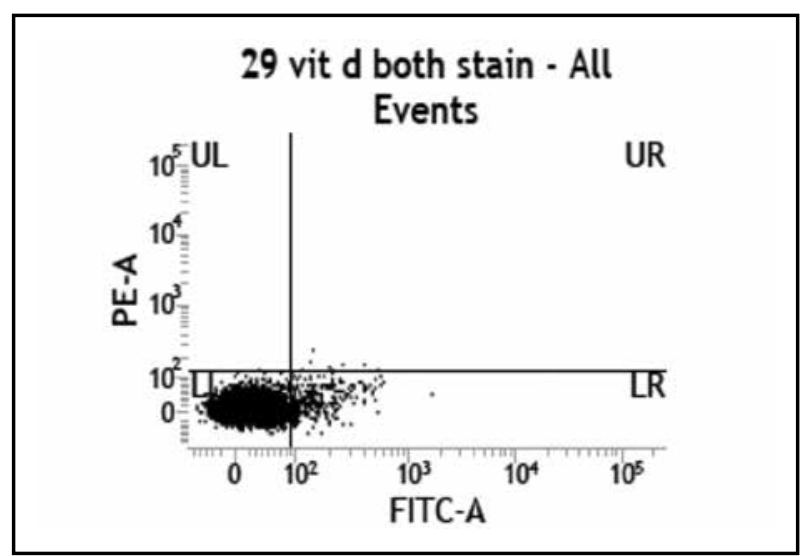

Fig. (3) Apoptotic changes in vitamin D-treated cells as shown on Flow Cytometer machine. AV: Annexin V, UL: upper right, UR: upper right, LL: lower left, LR: lower right

\section{DISCUSSION}

The present study was designed to obtain new information about the anti-cancer effect of vitamin D on head and neck squamous cell carcinoma cell line. Many data indicate that vitamin D deficiency raises the risk of developing cancer (4). The antineoplastic actions of calcitriol have been shown both in vitro and in vivo, in different malignancies ${ }^{(5-8)}$

The aim of the current study was to investigate the anti-cancer potential of $1,25(\mathrm{OH})_{2} \mathrm{D} 3$ on head and neck cancer cell line.

PrestoBlue cell proliferation and viability assay showed a dose-dependent cell inhibitory effect of $1,25(\mathrm{OH})_{2} \mathrm{D} 3$ on oral cancer cell line. That meant that the cell proliferation decreased when the $1,25(\mathrm{OH})_{2} \mathrm{D} 3$ concentration increased. This dosedependent effect manner was in accordance with that of Dalirsani et al. (2012) who studied the effect of vitamin $\mathrm{D}$ on the cell viability and proliferation in comparison to 5-fluorouracil and 13-cis on oral cancer cell line using MTT assay (4).

Flow cytometry results did not show a significant difference in apoptotic cells between treated and untreated groups. This may be due to the short treatment duration of one day.

Further in vitro and in vivo animal studies are needed to detrmine the mechanisms of vitamin D anti-cancer effects and to determine the therapuetic doses needed.

\section{REFERENCES}

1. Courthod G, Franco P, Palermo L, Pisconti S, Numico G. The role of microRNA in head and neck cancer: Current knowledge and perspectives. Molecules. 2014; 19(5): 5704-16

2. Díaz L, Díaz-Muñoz M, García-Gaytán AC, Méndez I. Mechanistic Effects of Calcitriol in Cancer Biology. Nutrients [Internet]. 2015 Jun [cited 2016 Feb 6];7(6):5020_ 50. Available from: http://www.pubmedcentral.nih.gov/ articlerender.fcgi?artid=4488829\&tool=pmcentrez\&rende rtype $=$ abstract 
3. Hauser B, Zhao Y, Pang X, Ling Z, Myers E, Wang P, et al. Functions of MiRNA-128 on the regulation of head and neck squamous cell carcinoma growth and apoptosis. PLoS One. 2015;10(3):1-15.

4. Feldman D, Krishnan A V., Swami S, Giovannucci E, Feldman BJ. The role of vitamin D in reducing cancer risk and progression. Nat Rev Cancer [Internet]. 2014;14(5):342-57. Available from: http://www.nature. com/doifinder/10.1038/nrc3691

5. Cheung FS, Lovicu FJ, Reichardt JK. Current progress in using vitamin D and its analogs for cancer prevention and treatment. Expert Rev Anticancer Ther [Internet]. 2012 Jun 10 [cited 2017 Mar 24];12(6):811-37. Available from: http://www.ncbi.nlm.nih.gov/pubmed/22716497
6. Leyssens C, Verlinden L, Verstuyf A. Antineoplastic effects of $1,25(\mathrm{OH}) 2 \mathrm{D} 3$ and its analogs in breast, prostate and colorectal cancer. Endocr Relat Cancer [Internet]. 2013 Apr 22 [cited 2017 Mar 24];20(2):R31-47. Available from: http://erc.endocrinology-journals.org/cgi/doi/10.1530/ ERC-12-0381

7. Mehta RG, Peng X, Alimirah F, Murillo G, Mehta R. Vitamin D and breast cancer: Emerging concepts. Cancer Lett [Internet]. 2013 Jun 28 [cited 2017 Mar 24];334(1):95-100. Available from: http://www.ncbi.nlm. nih.gov/pubmed/23142286

8. Leyssens C, Verlinden L, Verstuyf A. The future of vitamin D analogs. Front Physiol [Internet]. 2014 [cited 2017 Mar 24];5:122. Available from: http://www.ncbi.nlm.nih.gov/ pubmed/24772087 